\title{
The chloroplast genome sequencing of two important annual Trifolium species $T$. alexandrinum and $T$. resupinatum and comparative analysis with other congeneric species
}

yanli xiong

Sichuan Agricultural University

yi xiong

Sichuan Agricultural University

jun he

Southwest University

qingqing yu

Sichuan Agricultural University

junming zhao

Sichuan Agricultural University

xiong lei

Sichuan Agricultural University

zhixiao dong

Sichuan Agricultual University

jian yang

Sichuan Agricultural University

yan peng

Sichuan Agricultural University

xinquan zhang

Sichuan Agricultural University

Xiao Ma ( $D$ maroar@126.com )

Sichuan Agricultural University https://orcid.org/0000-0002-4491-3528

Research article

Keywords: chloroplast genome, divergence time, IR lacking, rearrangement, repetitive events, Trifolium

Posted Date: January 9th, 2020

DOI: https://doi.org/10.21203/rs.2.20410/v1 
License: (a) (i) This work is licensed under a Creative Commons Attribution 4.0 International License. Read Full License 


\section{Abstract}

Background: Chloroplast (cp) genome of most plant species has two typical inverted-repeats (IRs) regions. However, in some species this IR structure is lost for unknown reasons and the consequence still needs to be revealed. Here, we present whole cp genome sequencing of Trifolium alexandrinum (Egyptian clover) and $T$. resupinatum (Persian clover) from the IR lacking clade (IRLC). Results: Global aligning of $T$. alexandrinum and T. resupinatum to other eight Trifolium species revealed a large amount of rearrangement and repetitive events in these ten species. We found that IR lacking species have lower GC content and higher percentage of repetition than IR containing species. Abundant single nucleotide polymorphisms (SNPs) and insertions/deletions (In/Dels) were discovered between those two species. As hypothetical cp open reading frame (ORF) and RNA polymerase subunits severally, two genes ycf 1 and rpoC2 in the cp genomes, which both contain vast repetitive sequences and high Pi values $(0.6656,0.455)$ between $T$. alexandrinum and $T$. resupinatum, possessed highly variation among ten Trifolium species. Thus they could greatly influence evolutionary process of Trifolium species. In addition, IR containing and IR lacking Trifolium species were estimated to split during the upper Cretaceous period, which was potentially related to the violent crustal movement and sea-land changes. Conclusions: $\mathrm{Cp}$ genomes of $T$. alexandrinum and T. resupinatum, which belong to IRLC were sequenced and annotated in present study, and compared with cp genomes of other eight Trifolium species reported previously. This valuable information will provide insight into the evolution of IR lacking species. Nevertheless, further investigating of the detailed reason of IR lacking is still challenging, but it may be related to the violent crustal movement and sea-land changes of the Cretaceous period presented in this study.

\section{Background}

Trifolium L. (Papilionoideae), one of the largest genera in the Leguminosae, contains several important fodder species, such as T. repens (white clover), T. pretense (red clover), T. alexandrinum (Egyptian clover), T. resupinatum (Persian clover) and so on [1]. Trifolium species are also widely grown as green manure crops, and about 11 species including T. alexandrinum and T. resupinatum were introduced to subtropical zone of east Asia and have been reported to be excellently adapted to saline-alkali soil thus useful for agricultural production [2,3]. T. alexandrinum is generally grown as an annual winter legume fodder crop in the Middle East, Mediterranean and the Indian subcontinent. Its aerial part can be used for cattle feed and the seeds are used as an antidiabetic treatment [4]. Furthermore, T. alexandrinum also contributes to soil fertility and improves soil physical characteristics [4]. T. resupinatum, an annual, prostrate or semi-erect branched legume, can supply highly palatable and nutritive pasture and hay [5]. What's more, it is also very important as a park, garden and green place plant [1].

As an important part of plant organelles and photosynthetic organ, chloroplast (cp) has played an irreplaceable role in the plants [6]. The $\mathrm{cp}$ genomes are not only essential for the study of plants light system for potentially improving the photosynthetic capacity and thus increase plant yield, but also suitable for phylogenic study for their maternal inheritance and highly conserved genomic structure [7]. The cp genome has a typically covalently closed circular molecule structure including a small single-copy 
region (SSC), a large single-copy region (LSC) and two almost identical inverse repeats (IRs) regions [6]. A typical cp genome contains approximately 130 genes. Many of them participate in photosynthesis, some others also encode proteins or function in regulating gene transcription [7].

The IR regions with the average length between $10 \mathrm{~Kb}$ to $76 \mathrm{~Kb}$ were found in all families in the angiosperm plants and some gymnosperm and fern genus [8]. However, there are some exceptions like the clover genus (Trifolium) of the legume family (Leguminosae). Some species in Trifolium have a normal cp gnome and in some others the IR is lacking $[8,9]$. IR lacking $\mathrm{cp}$ genome only exists in species belong to "refractory clade" of Trifolium L., which includes the Trifolium sections Lupinaster, Trifolium, Tricocephalum, Vesicastrum and Trifoliastrum [9]. Large quantities of repeated DNA, which are the main resource of sequence variation and allowed to appropriately assess the phylogenetic relationships, are found to typically exist in IR lacking subclover ( $T$. subterraneum) based on the previous studies [10]. Those repetitive structure might cause sequence rearrangement via intra homologous recombination [8].

Leguminosae are accepted to have flourished since the Cretaceous period and IR is considered as the major feature of the cp genome in plants since 400 million of years ago (Mya). However, the time of divergence between IR lacking and IR containing species has not been reported yet. Phylogenetic relationships between IR containing and IR lacking species of Trifolium were well estimated using 58 protein-coding genes in cp genomes [10]. However, T. alexandrinum and T. resupinatum have not been studied yet. Variation among different species could provide a fascinating glimpse into the understanding of plant biology and diversity [7].

Here, cp genomes of $T$. alexandrinum and $T$. resupinatum were sequenced and annotated using next generation sequencing (NGS). We compared the sequence differences caused by nucleic acid polymorphism ( $\mathrm{Pi})$, In/Del and repetitive sequences, as well as the evolution pressure reflected by nonsynonymous/synonymous (Ka/Ks) between these two species. Furthermore, these two species were compared with other eight (four IR containing species and four IR lacking species of Trifolium) congeneric species and divergent times were estimated. This study provides insights into evolution of IR lacking $\mathrm{cP}$ genomes.

\section{Results}

\section{Features of the $T$. alexandrium and $T$. resupinatum cp genomes}

More than 20 million ReadSum (pair-end reads) were yielded for T. alexandrium and T. resupinatum, with the Q20 and Q30 (the percentage of bases whose mass value is greater than or equal to 20,30) were higher than $94 \%$ and $87 \%$, respectively. We assembled them successfully based on the alignment of pairedend sequences to the reference of $T$. medeseum (Fig 1). The cp genomes of $T$. alexandrium and $T$. resupinatum were detected with IR lacking and have a size of 148,545 bp and 149,026 bp, respectively (Table 1). The GC content in the two cp genomes was about $34.09 \%$ and $33.80 \%$ overall, and $37.05 \%$ and $36.64 \%$ in coding sequences (CDS). A total of 112 and 109 genes were consisted in the complete cp genomes of $T$. alexandrinum and T. resupinatum, which were contained 31 and 37 tRNA, 75 and 66 mRNA, and 6 rRNA, and 13 and five genes possessing introns, respectively. 
Table 1 Comparison of the ten species of Trifolium genus

\begin{tabular}{|c|c|c|c|c|c|c|c|c|c|c|}
\hline \multirow[t]{2}{*}{ Species } & \multirow{2}{*}{$\begin{array}{c}\text { Genome } \\
\text { length(bp) } \\
\text { repetitive } \\
\%\end{array}$} & \multicolumn{2}{|c|}{ GC content $(\%)$} & \multirow{2}{*}{$\begin{array}{c}\text { Gene } \\
\text { density }\end{array}$} & \multirow[t]{2}{*}{ tRNA } & \multirow[t]{2}{*}{ rRNA } & \multirow[t]{2}{*}{ mRNA } & \multirow[t]{2}{*}{ genes } & \multirow{2}{*}{$\begin{array}{l}\text { genes } \\
\text { with } \\
\text { exons }\end{array}$} & \multirow{2}{*}{$\begin{array}{c}\text { GenBank } \\
\text { number }\end{array}$} \\
\hline & & $\begin{array}{c}\text { cp } \\
\text { Genome }\end{array}$ & CDS & & & & & & & \\
\hline \multirow{2}{*}{ T. alexandrinum } & 148545 & \multirow[t]{2}{*}{34.09} & \multirow[t]{2}{*}{37.05} & \multirow{2}{*}{$\begin{array}{l}7.54 \mathrm{E}- \\
04\end{array}$} & \multirow[t]{2}{*}{31} & \multirow[t]{2}{*}{6} & \multirow[t]{2}{*}{75} & \multirow[t]{2}{*}{112} & \multirow[t]{2}{*}{13} & \multirow[t]{2}{*}{ MN857160 } \\
\hline & $2.85 \%$ & & & & & & & & & \\
\hline \multirow[t]{2}{*}{ T. resupinatum } & 149026 & \multirow[t]{2}{*}{33.8} & \multirow[t]{2}{*}{36.64} & \multirow{2}{*}{$\begin{array}{l}\text { 7.31E- } \\
04\end{array}$} & \multirow[t]{2}{*}{37} & \multirow[t]{2}{*}{6} & \multirow[t]{2}{*}{66} & \multirow[t]{2}{*}{109} & \multirow[t]{2}{*}{5} & \multirow[t]{2}{*}{ MN857161 } \\
\hline & $2.69 \%$ & & & & & & & & & \\
\hline \multirow[t]{2}{*}{ T. subterraneum } & 144763 & 34.83 & 37.1 & 7.60E- & 30 & 4 & 76 & 110 & 16 & NC011828 \\
\hline & $20.71 \%$ & & & 04 & & & & & & \\
\hline T. meduseum & 142595 & 34.87 & 37.34 & $7.78 \mathrm{E}-$ & 30 & 4 & 77 & 111 & 10 & NC476730.1 \\
\hline & $12.83 \%$ & & & & & & & & & \\
\hline T. pratense & 121178 & 34.63 & 36.94 & 7.43E- & 28 & 4 & 58 & 90 & 9 & KJ788290 \\
\hline & NA & & & & & & & & & \\
\hline T. repens & 132120 & 34.53 & 36.96 & $8.10 \mathrm{E}-$ & 31 & 4 & 72 & 107 & 10 & KC894706.1 \\
\hline & $20.70 \%$ & & & & & & & & & \\
\hline T.strictum* & 125834 & 34.98 & 36.7 & 8.82E- & 31 & 5 & 75 & 111 & 11 & NC025745.1 \\
\hline & $0.71 \%$ & & & & & & & & & \\
\hline T.aureum* & 126970 & 34.86 & 36.81 & $8.51 \mathrm{E}-$ & 30 & 4 & 74 & 108 & 9 & KC894708.1 \\
\hline & $5.60 \%$ & & & & & & & & & \\
\hline T.boissieri* & 125740 & 35.24 & 36.83 & $8.75 \mathrm{E}-$ & 31 & 5 & 74 & 110 & 9 & NC025743.1 \\
\hline & $1.05 \%$ & & & & & & & & & \\
\hline T.glanduliferum* & 126149 & 34.9 & 36.7 & $8.72 \mathrm{E}-$ & 30 & 5 & 75 & 110 & 11 & NC025744.1 \\
\hline & $0.78 \%$ & & & 04 & & & & & & \\
\hline Mean of IR & 126173.25 & 34.45 & 37.01 & 7.63E- & 31.17 & 4.67 & 70.67 & 106.5 & 10.5 & \\
\hline lacking species & $11.96 \%$ & & & 04 & & & & & & \\
\hline Mean of IR & 139704.5 & 35 & 36.76 & 8.70E- & 30.5 & 4.75 & 74.5 & 109.75 & 10 & \\
\hline $\begin{array}{c}\text { containing } \\
\text { species }\end{array}$ & $2.04 \%$ & & & 04 & & & & & & \\
\hline
\end{tabular}

There were 46 genes related to photosynthesis in $\mathrm{cp}$ genomes of $T$. alexandrinum and T. resupinatum (Table 2), of which four genes $p s b N$, atpF, $n d h A$ and $n d h B$ were specific for $T$. alexandrinum. These genes include the ones encoding subunit of Rubisco, subunits of photosystem I, subunits of photosystem II, subunits of ATP synthase, cytochrome $b / f$ complex, c-type cytochrome synthesis and subunits of NADH dehydrogenase. Thirty-one genes were related to self-replication, including four ribosomal RNA genes and 27 transfer RNA genes, in which trnT-CGU was unique in T. alexandrinum. Besides, ten genes encoding ribosomal proteins and twelve were associated with transcription. Among them, $r p s 18, r p / 2$ and $r p o C 1$ were unique in $T$. alexandrinum. Furthermore, two genes $c l p P$ and $y c f 3$ with other functions were particular for $T$. alexandrinum (Additional file1: Table S1).

Introns are not subject to natural selection thus theoretically accumulate more mutations than exons. In this study, a total of seven genes ( $a t p F, c l p P, n d h A, n d h B, r p o C 1, r p s 18$ and $t R N A-C G U$ ) only contained an intron in T. alexandrinum (Additional file1: Table S1). Other five genes tRNA-UAA, tRNA-UAC, tRNA-UGC, IRNA-UUC and tRNA-UUU all had an intron in T. alexandrinum and T. resupinatum. The exons length of 
those five genes was more conserved compared with intron. In particular, $y c f 3$ had two introns in $T$. alexandrinum.

Table 2 List of genes annotated in the cp genomes of T. alexandrinum and T. resupinatum.

\begin{tabular}{|c|c|c|c|c|c|c|c|}
\hline Category & Function & \multicolumn{6}{|c|}{ Name of gene } \\
\hline \multirow[t]{6}{*}{ Self-replication (31) } & $\begin{array}{c}\text { Ribosomal RNA } \\
\text { Genes }\end{array}$ & $\operatorname{rrn} 4.5$ & rrn5 & $\operatorname{rrn} 16$ & $\operatorname{rrn} 23$ & & \\
\hline & Transfer RNA genes & $\operatorname{trn} A-A C G$ & $\operatorname{trn} A-G U C$ & $\operatorname{trn} A-G U U$ & $\operatorname{trn} A-U C U$ & $\begin{array}{l}\operatorname{trn} A- \\
U G C^{*}\end{array}$ & $\begin{array}{l}\operatorname{trn} C- \\
G C A\end{array}$ \\
\hline & & $\operatorname{trn} G-G C C$ & $\operatorname{trn} G-U U C^{*}$ & $\operatorname{trnG-UUG}$ & $\operatorname{trn} H-G U G$ & $\begin{array}{c}\operatorname{trn} L- \\
C A A\end{array}$ & $\begin{array}{l}\operatorname{trn} L- \\
U A A^{*}\end{array}$ \\
\hline & & $\operatorname{trn} L-U A G$ & $\operatorname{trnL}-U U U^{*}$ & $\operatorname{trn} M-C A U$ & $\operatorname{trn} P-G A A$ & $\begin{array}{l}\operatorname{trn} P- \\
U G G\end{array}$ & $\begin{array}{l}\operatorname{trn} S- \\
G C U\end{array}$ \\
\hline & & $\operatorname{trn} S-G G A$ & $\operatorname{trn} S-U G A$ & $\operatorname{trn} T-C C A$ & $\begin{array}{c}\operatorname{trnT} T- \\
C G U^{*} \text { (ale) }\end{array}$ & $\begin{array}{l}\operatorname{trnT}- \\
G G U\end{array}$ & $\begin{array}{l}\operatorname{trnT} T- \\
G U A\end{array}$ \\
\hline & & $\operatorname{trn} T-U G U$ & $\operatorname{trn} V-G A C$ & $\operatorname{trn} V-U A C^{*}$ & & & \\
\hline \multirow[t]{2}{*}{$\begin{array}{l}\text { Ribosomal proteins } \\
(10)\end{array}$} & $\begin{array}{l}\text { Small subunit of } \\
\text { ribosome (SSU) }\end{array}$ & rps2 & rps3 & rps4 & rps 7 & rps8 & rps11 \\
\hline & & rps14 & rps15 & rps18*/ale & rps19 & & \\
\hline \multirow[t]{3}{*}{ Transcription (12) } & $\begin{array}{l}\text { Large subunit of } \\
\text { ribosome (LSU) }\end{array}$ & rpl2 (ale) & rpl14 & rpl16 & rpl20 & rpl23 & rpl32 \\
\hline & & rpl33 & rpl36 & & & & \\
\hline & $\begin{array}{l}\text { RNA polymerase } \\
\text { subunits }\end{array}$ & rpoA & $r p o B$ & $r p o C 1^{*}$ (ale) & rрос2 & & \\
\hline \multirow[t]{10}{*}{$\begin{array}{c}\text { Photosynthesis } \\
\text { related genes (46) }\end{array}$} & $\begin{array}{l}\text { Large subunit of } \\
\text { Rubisco }\end{array}$ & $r b c L$ & & & & & \\
\hline & $\begin{array}{c}\text { Subunits of } \\
\text { Photosystem I }\end{array}$ & $p s a A$ & $p s a B$ & psaC & $p s a I$ & $p s a J$ & $y c f 4$ \\
\hline & $\begin{array}{c}\text { Subunits of } \\
\text { Photosystem II }\end{array}$ & $p s b A$ & $p s b B$ & $p s b C$ & $p s b D$ & $p s b E$ & $p s b F$ \\
\hline & & $p s b H$ & $p s b I$ & $p s b J$ & $p s b K$ & $p s b L$ & $p s b M$ \\
\hline & & $p s b N($ ale) & $p s b T$ & $p s b Z$ & & & \\
\hline & $\begin{array}{c}\text { Subunits of ATP } \\
\text { synthase }\end{array}$ & $a t p A$ & $\operatorname{atp} B$ & atpE & atpF* (ale) & atpH & atpI \\
\hline & $\begin{array}{l}\text { Cytochrome b/f } \\
\text { complex }\end{array}$ & petA & petB & petD & petG & petL & petN \\
\hline & $\begin{array}{l}\text { C-type cytochrome } \\
\text { synthesis gene }\end{array}$ & $\operatorname{Ccs} A$ & & & & & \\
\hline & $\begin{array}{l}\text { Subunits of NADH } \\
\text { dehydrogenase }\end{array}$ & $n d h A^{*}$ (ale) & $n d h B^{*}$ (ale) & $n d h C$ & $n d h D$ & $n d h E$ & $n d h F$ \\
\hline & & $n d h G$ & $n d h H$ & $n d h I$ & $n d h J$ & $n d h K$ & \\
\hline \multirow[t]{5}{*}{ Other genes (7) } & Maturase & matK & & & & & \\
\hline & Protease & $\operatorname{clp} P^{*}$ (ale) & & & & & \\
\hline & $\begin{array}{l}\text { Chloroplast envelope } \\
\text { membrane protein }\end{array}$ & $\operatorname{cem} A$ & & & & & \\
\hline & Subunit of acetyl-CoA & $a c c D$ & & & & & \\
\hline & $\begin{array}{l}\text { Hypothetical open } \\
\text { reading frames }\end{array}$ & $y c f 1$ & ycf2 & $y c f 3^{* *}$ (ale) & & & \\
\hline
\end{tabular}

Note: ${ }^{*}$, Genes containing a single intron; ${ }^{* *}$, Genes containing two introns; (ale), Genes that are particular for Trifolium alexandrinum; */ale, Genes that only have an intron in Trifolium alexandrinum.

\section{Repeats analysis}

Scattered repeating sequences (palindrome repeats and direct repeats) and simple sequencing repeats (SSRs) were analyzed respectively. Over all, percentage of repetitive sequences in IR containing species (2.035\%, Table 1) was less than those IR lacking species (11.956\%). A total of 1941 scattered repetitive sequences in T. alexandrinum cp genome were annotated, which was greater than T. resupinatum (1250). 
The percentages of palindrome repeats (type $\mathrm{P}, 50.49 \%$, Fig 2B) of $T$. alexandrinum were slightly larger than T. resupinatum (46.4\%). A total of 370 (Fig 2A) and 383 SSRs (sizes ranged from $8-81$ bp and $8-36$ bp) were predicted in $T$. alexandrinum and T. resupinatum and $30.54 \%$ and $23.24 \%$ of them were distributed in genic regions. In particular, the majority of SSRs were located in ycf1 (18 for T. alexandrinum and $T$. resupinatum), followed by rpoC2 ( 11 for $T$. resupinatum and 9 for $T$. alexandrinum). The mononucleotide repeats were dominant $(65.41 \%$ in $T$. alexandrinum and $74.93 \%$ in $T$. resupinatum), followed by trinucleotide repeats $(25.68 \%$ in $T$. alexandrinum and $22.19 \%$ in $T$. resupinatum), in which the repeats of the polyadenine (poly A, $37.34 \%$ for $T$. resupinatum and $35.95 \%$ for $T$. alexandrinum) and polythymine (poly $T$, $36.55 \%$ for $T$. resupinatum and $37.84 \%$ for $T$. alexandrinum) were much more than guanine (G) or cytosine (C) repeats (less than 1.35\%). A total of 24 SSRs were identified to be shared by $T$. alexandrinum and $T$. resupinatum (Additional file2: Table S2; Fig 2A). The common repeat sequences larger than 30 bp with the longest length of $117 \mathrm{bp}$ was showed in Fig 2C.

\section{The relative synonymous codon usage analysis}

The relative synonymous codon usage analysis (RSCU), which is considered to be a combination result of natural selection, species mutation and genetic drift, was analyzed (Fig 3; Additional file3: Table S3). The value for initiation codon AUG (RSCU $=2.9745)$ was much greater than GUG (RSCU $=0.0129)$. The values of three termination codons UAA, UAG and UGA were $1.6215,0.5676$ and 0.8109 . A total of $46.97 \%$ (31 of 66 , include three termination codons) of the codons were with the greater codon frequency (RSCU values more than one), in which $93.55 \%$ (29 of 31 ) were prefer $A$ or $U$ in the third sites. In the other codons with RSCU values less than one (including one), C or G were more general in the third position $(88.57 \%, 31$ of $35)$.

\section{$\mathrm{Ka} / \mathrm{Ks}$, single nucleotide polymorphisms (SNPs) and insertions/deletions (In/Dels)}

Single nucleotide polymorphisms (SNPs), mainly including transversion (Tv) and transition (Tn), along with insertions/deletions (In/Dels) could lead the non-synonymous (Ka) or synonymous (Ks) substitution. The total SNPs and In/Dels in every gene varied from 1 ( $n d h E$ and $p s a C$ ) to 677 (atpB) with the total of 8560. Additionally, more In/Dels, Tn and Tv were detected in intergenic regions (5.66\%, $17.11 \%$ and $38.70 \%$ ) than genic regions $(3.05 \%, 10.40 \%$ and $25.08 \%$ ) (Fig 4; Additional file4: Table S4). The 62 shared protein-coding genes with variations were used to calculate the Ka/Ks (Additional file5: Table S5). The values of $\mathrm{Ka}$ and Ks were ranged from 0 ( $n d h E$, petD, psal, psbA, psbB and so on) to 3.0151 (rps4) and 0 (petG, petN, trnR$A C G$, trnL-CAA, trnl-CAU, trnl-CAU and so on) to 2.9415 (rps8) and Ka/Ks varied from 0 ( $n d h E$, psbZ, psbA, $p s b J$ and so on) to 3.7723 (rps4, Fig 5), respectively. Nine genes including rpoC2, ndhG, trnK-UUU, ccsA, $n d h F, y c f 1, r p s 4, p s a C$ and $r r n 4.5$ have $\mathrm{Ka} / \mathrm{Ks}$ values above one, implying positive selection on these genes. The $\mathrm{Pi}$ values calculated by 88 common genes of $T$. alexandrinum and $T$. resupinatum were from 0 to 0.7867 (trnl-CAU). Twenty-one genes had a Pi values of 0 . Ninteen of them were tRNA. The nine genes with $\mathrm{Ka} / \mathrm{Ka}$ above one also possessed relatively high Pi values (Fig 6; Additional file6: Table S6).

\section{Wholecp genome comparison with other Trifolium species}


In order to excavate the sequence divergence of Trifolium genus and further shed light on the evolutionary events, such as pseudogenization, gene mutation, rearrangement and gene loss, cp genomes of ten species including four IR containing species ( $T$. aureum, T. boissieri, T. glanduliflerum and T. strictum) and six IR lacking species ( $T$. alexandrinum, $T$. resupinatum, $T$. repens, $T$. pratense, $T$. subterraneum and $T$. meduseum) were compared. The results indicated that the average size of $\mathrm{cP}$ genomes of these IR lacking species (126173.25 bp, Table 1) and genic density (7.63E-04) were lower than the ones containing IR (139704.5 bp, 8.70E-04), and the latter held higher mean GC content of whole cp genome (35.00\%). Only minor variations were detected in the total numbers of genes, tRNA and mRNA among the selected species. T. pratense possessed the smallest numbers of tRNA (28), mRNA (58) and total number of genes (90).

Furthermore, abundant gene rearrangements were detected among ten Trifolium species using MAUVE program and the T. subterraneum as the reference sequence (Fig 7). Compared with CDS, non-coding sequences (CNS) showed most significant variation among selected Trifolium species (Fig 8). In other words, sequences variation in genic regions was lower than intergenic regions in the cp genomes of those ten species.

\section{Phylogenetic divergence time estimation}

The CDS of 76 genes shared in cp genomes of the 20 species (18 of Papilionoideae, one of Caesalpinioideae and one of Mimosaceae) were subjected to phylogeny analysis and divergence times estimation (Fig 9). The topological structure of phylogenetic tree was almost consistent with the classification of Leguminosae with strong bootstrap support. Three subfamilies Papilionoideae, Caesalpinioideae and Mimosaceae were clearly separated. It is worth noting that Glycine max and Lotus japonicus, belonging to Papilionoideae, were evolutionally grouped with Ceratonia siliqua (Caesalpinioideae) and Albizia odoratissima (Mimosaceae). Trifolium species split from Medicago species during the Early Cretaceous (127.2288 Mya). It seems that during the Late Cretaceous (83.5049 Mya), the IR lacking Trifolium species diverged with IR containing Trifolium species.

\section{Discussion}

\section{Base mutation of $T$. alexandrinum and $T$. resupinatum to IR containing species}

Point mutation was generally more common than frame shift for natural mutation [19]. As expected, more SNPs (21963, 6618 Tn and 15345 Tv; Additional file4: Table S4) than In/Del (2097) were found between $T$. alexandrinum and T. resupinatum. What's more, $60 \%$ of them occurred in intergenic regions, which was consistent with the conservatism of CDS displayed in mVISTA (Fig 6). This discovery was in agreement with the hypothesis that CDS had a slower rate of evolution compared with CNS [20]. Furthermore, minuscule SNPs (159 between Oryza sativa and $O$. nivara [21], 330 between Citrus sinensis and $C$. aurantiifolia [22] and 231 between Machilus yunnanensis and $M$. balansae [23]) were identified in IR containing species, which were exceptionally smaller than the SNPs between two IR lacking species $T$. alexandrinum and $T$. resupinatum calculated in present study. As an important structure in stabilizing $\mathrm{cp}$ 
genome, IR region can hold from deviating by selective force [24]. Thus the observed abundant SNPs/Indels in T. alexandrinum and T. resupinatum are not surprising.

The comparison between the Ka and Ks of genes is an important content of molecular evolution [25]. Most genes were subjected to the neutral selection and purification selection, however, there are also limited genes whose rate of $\mathrm{Ka}$ is higher than that of $\mathrm{Ks}$ because the function of the gene has been dramatically changed, called Darwinian positive selection [26]. Lacking one IR region is believed to directly enhance the nucleotide substitution rate of the single repeat sequence. Previous studies have shown that in the IR lacking $\mathrm{cp}$ genome, the nucleotide substitution rate in the remaining repeat region is comparable to that of the single repeat region, which is 2.3 times higher than that in the IR containing cp genome [27]. Here, seven protein-coding genes in the cp genome of $T$. alexandrinum and $T$. resupinatum (rps4, rpoC2, ndhG, $\operatorname{ccs} A, n d h F, y c f 1$ and $p s a C$ ) have high ratio of $\mathrm{Ka}$ to $\mathrm{Ks}$, which led by high values of Ka but extremely low values of Ks, could imply that they are under positive selection and played an important role in enhancing individual adaptability in evolutionary process. rps4 [28] and rpoC2 [29] have been reported to be under positive selection in previous studies. However, beneficial mutations might be fixed in those genes and, thus, reduce genetic polymorphism at selected sites [30].

\section{Global alignment between IR containing and IR lacking Trifolium species}

Comparing the cp genomes of $T$. alexandrinum and $T$. resupinatum sequenced in present study to other eight (four IR containing species) Trifolium species showed relatively high conserved genome length and gene content though $T$. pretense possessed only 90 genes (Table 1). Furthermore, the high average GC content, which forms a more stable structure of genome, were observed in four IRs containing species ( $T$. strictum, T. aureum, T. boissieri and T. glanduliferum) compared with IR lacking species (Table 1). According to Millen et al. [31], the vast of angiosperms held in shared 74 coding-protein genes but other five genes ( $a c c D, y c f 1, y c f 2, r p / 23$ and infA) were only existed in some specific species. $Y c f 1$, with the premature stop codons in the CDS thus always be defined as pseudogene or ORF in other angiosperm [32], was present in all the ten Trifolium species and with the biggest value of Pi (0.6656; Additional file6: Table S6) among 76 common genes in ten species. This is closely related to the fact that most pseudogenes have undergone the processes of accelerated mutation rate, decreased GC content, and decreased secondary structure stability [33]. Therefore, ycf1 possesses considerable variation among different species thus could be considered as the good candidate gene for phylogenic study among Trifolium species.

As the driving force of evolution, repetitive sequences indicate that the genetic material of a species is continuously self-replicating in the process of evolution, thus greatly expanding and enriching the genetic information [34]. Present study revealed higher repetitive percentage $(11.96 \%$, Table 1$)$ in IR lacking species than IR containing species (2.04\%). The number of repeated sequences in $\mathrm{cp}$ genome are associated with rearrangement in some species [35]. However, the driving force of repetitive sequence was seemly related to nuclear genes and genomic recombination [10], such as homologous recombination and microhomology-mediated break-induced replication acting on more than $50 \mathrm{bp}$ and less than $30 \mathrm{bp}$ repeats, respectively. Known as "hotspots" for variation [36], ycf1 and rpoC2, highly varied among ten 
Trifolium species (Fig 8), possessed the majority of repetitive sequences in T. alexandrinum and $T$. resupinatum and high values of $\mathrm{Pi}$, thus could have essential function in the evolutionary process of Trifolium species.

In general, there is a strong correlation between the presence of IR and structurally stabilization of $\mathrm{cp}$ genomes. Substantial rearrangement was usually found in cp genomes lacking IR [9]. Among those IR lacking species of Leguminosae such as alfalfa, subclover, pea, etc, some are structurally stable and have not been rearranged, some undergo intermediate rearrangements, while others experienced a series of complex rearrangements [9]. This study found abundant rearrangements within six IR lacking species or four IR containing cp genomes of Trifolium (Fig 7). According to Palmer and Thompson [8], IR could prevent the rearrangement of $\mathrm{cp}$ sequence to some extent, so the rearrangement probability will be increased in the species lacking IR sequence. However, some species of legumes were reported having obtained the ability to increase rearrangement, this could be why there are many rearrangement events detected among those ten Trifolium species [8]. However, lacking IR leads to increased rearrangement is only one of the explains.

\section{Phylogeny analysis and divergent time}

The topological structure of other eight Trifolium species using 76 protein coding genes in this study was generally in agreement with the report of Sveinsson and Cronk [9] by 58 protein coding genes. In addition, the phylogenetic location of tested T. alexandrinum and T. resupinatum was confirmed (Fig 9).

Furthermore, T. alexandrinum and T. pratense, both belonging to Trifolium Sect. Trifolium, were clustered together and $T$. resupinatum was grouped with $T$. repens though those two species were in a separate group in Malaviya's study based on isozyme data [37]. Two IR containing species $T$. boissieri and $T$. aureum were predicted to differentiate with other eight species in late Cretaceous period, then another two IR containing species $T$. strictum and T. glanduliferum were further diverted with IR lacking species at about 14 Mya. In late Cretaceous period, violent crustal movement and sea-land changes led to a flourished development of angiosperms and IR lacking species might form at the same time. It looks as if the ancestor of some IR lacking species had gone through a battery of evolutionary alternation (including high rearrangement and repetition) and the precise mechanism of such evolutionary pattern is underway to illuminate.

\section{Conclusion}

Cp genomes of T. alexandrinum and T. resupinatum, which belong to inverted-repeat-lacking clade (IRLC) were sequenced and annotated in present study, and compared with cp genomes of other eight Trifolium species reported previously. The results revealed a high variation in CDS and abundant rearrangement within Trifolium genus. Compared to IR containing species, IR lacking species held lower GC content, higher SNP, In/Del and repeats. This valuable information will provide insight into the evolution of IR lacking species. Nevertheless, further investigating of the detailed reason of IR lacking is still challenging, but it may be related to the violent crustal movement and sea-land changes of the Cretaceous period presented in this study. 


\section{Methods}

\section{Plant material, DNA isolation and sequencing}

Plant seeds of $T$. alexandrinum (cv 'Elite II') and T. resupinatum (cv 'Laser') were kindly provided by Barenbrug (Australia) then germinated in growth chamber $\left(25^{\circ} \mathrm{C}, 300 \mu \mathrm{mols} \cdot \mathrm{m}^{2} \cdot \mathrm{s}^{-1} ; 16\right.$-h photoperiod). Total DNA was extracted from $50 \mathrm{mg}$ of fresh leaves following the Plant DNA Isolation Kit (Tiangen, Beijing). Sequencing was performed on Illumina Novaseq sequencing platform (Illumina, San Diego, CA) according to protocol of Illumina manual (San Diego, CA, USA). Sheared low molecular weight DNA fragments were used to construct paired-end (PE) libraries then sequenced by Genepioneer Biotechnologies (Nanjing, China).

\section{Cp genome assembly, annotation and visualization}

Both the raw data for two Trifolium species were filtered according to the following criterion: reads of less than $5 \%$ unidentified nucleotides and more than $50 \%$ of its bases with the quality score of $₫ 20$ were retained after adapter trimming. With the reference genome of T. meduseum [10] (National Center for Biotechnology Information, NCBI number KJ 788288), the cp DNA were assembled as follows. In order to decrease the difficulty of sequences assemble, filtered reads (clean data) were aligned to the cp genome database built by Genepioneer Biotechnologies (Nanjing, China) using bowtie2 v 2.2.4 and SPAdes v3.10.1 to acquire SEED sequences then obtained contigs by kmer iterative extend seed. Scaffolds connected by contigs using SSPACE v 2.0 were filled gap by Gapfiller v 2.1.1 until gain the integrated cp genome.

The results of CDS and rRNA were obtained using BLAST V 2.2.25 and HMMER V3.1 b2 via aligned to cp genome database of NCBI. ARAGORN V 1.2.38 and tRNAscan-SE search server (http://lowelab.ucsc.edu/tRNAscan-SE/) were used to predict and further check tRNA. Finally, the result of genome annotation was performed via Geneious (https://www.geneious.com, [11]) and visualized in OGDRAW (https://chlorobox.mpimp-golm.mpg.de/OGDraw.html).

\section{The relative synonymous codon usage analysis (RSCU) and simple repeating sequences (SSRs) prediction}

The RSCU was analyzed using MEGA v7.0 to reflect the relative preference of a particular codon encoding the corresponding amino acid codon [12]. The values of RSCU more than one was considered as greater codon frequency. SSRs with the same repeats units and times and distributed in the genic regions were considered as shared repeats, the repetitive sequences were distinguished using VMATCH V2.3.0 (http://www.vmatch.de/) and MISA v1.0 (http://pgrc.ipk-gatersleben.de/misa/misa.html) based on the genomic data, which was also utilized to determine the mono-, di-, tri-, tetra-, penta- and hexa- nucleotides.

\section{Sequence variation analysis and $\mathrm{Ka} / \mathrm{Ks}$}

Whole cp genome alignment and collinearity analysis of sequenced species herein along with eight Trifolium species, namely T. strictum (NC025745.1, [9]), T. aureum (KC894708.1, [10]), T. boissieri (NC025743.1, [9]), T. glanduliferum (NC025744.1, [9]), T. subterraneum (NC011828, [13]), T. meduseum 
(NC476730.1, [9]), T. pratense (KJ788290, [9]) and T. repens (KC894706.1, [10]) was implemented using Mauve [14] and mVISTA [15], respectively. Among those species, the former four contain IR and the latter four lack IR. Furthermore, the common genes of T. alexandrium and T. resupinatum tested in present study were utilized for $\mathrm{Ka} / \mathrm{Ks}$ and nucleotide diversity $(\mathrm{Pi}$ ) calculation. $\mathrm{Ka} / \mathrm{Ks}$, which was generally considered as a reflection of selection pressures, was computed via KaKs_Calculator v2.0 [16]. Pi, which could be used to estimate the degree of nucleotide sequences variation and further provide potential molecular markers for population genetics, was calculated using VCFTOOLS by sequences comparison of the CDS of the common genes of different species by MAFFT version 7.017 [17]. Finally, single nucleotide polymorphisms (SNPs) and insertions/deletions (In/Dels) of T. alexandrium and T. resupinatum were also identified using Mafft program [17].

\section{Divergence time estimates}

A total of 20 Leguminosae species including 18 Papilionoideae, one Caesalpinioideae and one Mimosaceae were utilized to assess the divergence time using BEAST v 1.7.3 package [18] with the Bayesian method. GTR+G+I substitution model with strict clock model and Yule model for Priors tree were applied for BEAUti along with MCMC analysis setting as follows, 10,000,000 of Chain length, 1,000 of Tracelog, 1,000 of screenlog, 1,000 of treelog.t: tree. The assessment of results was executed in Tracer $\mathrm{V}$ 1.5 (http://www.beast.bio.ed.ac.uk/) to confirm that the value of effective sample size (ESS) was greater than 200. Finally, the document of "tree" obtained from TreeAnnotator was visualized in Figtree v1.4.3 (http://tree.bio.ed.ac.uk/software/figtree/).

\section{Abbreviations}

Cp: Chloroplast; IRs inverted-repeats; IRLC: IR lacking clade; SNP: single nucleotide polymorphisms; In/Dels: insertions/deletions; ORF: open reading frame; SSC: small single-copy region; LSC :large single-copy region; NGS: next generation sequencing; Pi: nucleic acid polymorphism; Ka: non-synonymous; Ks:

synonymous; SSRs: simple sequencing repeats; RSCU: the relative synonymous codon usage analysis; Tv: transversion; Tn: transition; CDS: coding sequences; CNS: non-coding sequences; UTR: untranslated regions

\section{Declarations}

\section{Ethics approval and consent to participate}

Not applicable

\section{Consent for publication}

Not applicable

\section{Consent for publication}


Not applicable

\section{Availability of data and materials}

The annotated chloroplast genomes of $T$. alexandrinum and T. resupinatum have been deposited in the NCBI GenBank with the accession numbers MN857160 and MN857161.

\section{Competing interests}

The authors declare that they have no competing interests.

\section{Funding}

This research was supported by the earmarked fund for Modern Agro-industry Technology Research System (No. CARS-34) and National Natural Science Foundation of China (3177131276).

\section{Authors' contributions}

$\mathrm{XM}, \mathrm{YP}$ and $\mathrm{YLX}$ conceived and designed the study. YLX and YX participated in assembly and sequence analysis and wrote the draft paper. QQY and JMZ cultured and maintained the experimental material. ZXD and JY participated in the assembly of the genome sequences. $X Q Z$ and $Y X$ performed sequence analyses and generated the figures. $\mathrm{JH}$ and $\mathrm{XL}$ analyzed the data and prepared tables. All authors read and approved the final manuscript.

\section{Acknowledgements}

We thank test support of laboratory staff in the Department of Grassland Science, Animal Science and Technology College, Sichuan Agricultural University.

\section{Authors' information}

${ }^{1}$ College of Animal science and Technology, Sichuan Agricultural University, Chengdu, China. ${ }^{2}$ State Key Laboratory of Exploration and Utilization of Crop Gene Resources in 10 Southwest China, Key Laboratory of Biology and Genetic Improvement of Maize in 11 Southwest Region, Ministry of Agriculture, Maize Research Institute of Sichuan 12 Agricultural University, Chengdu 600031, China.

\section{References}

1. Sabudak T, Guler N. Trifolium L. - A review on its phytochemical and pharmacological profile. Phytotherapy Research. 2009;23(3):439-446. doi:10.1002/ptr.2709.

2. Steiner JJ. Molecular phylogenetics of the clover genus (Trifolium-Leguminosae). Molecular Phylogenetics \& Evolution. 2006;39(3):688-705. doi:10.1016/j.ympev.2006.01.004.

3. Turpin JE, Herridge DF, Robertson MJ. Nitrogen fixation and soil nitrate interactions in field-grown chickpea (Cicer arietinum) and fababean (Vicia faba). Crop \& Pasture Science. 2002;53(5):599-608. 
doi: 10.1071/AR01136.

4. Bakheit RB. Egyptian clover (Trifolium alexandrinum L.) breeding in Egypt. Asian Journal of Crop Sci. 2013;5:325-337. doi:10.3923/ajcs.2013.

5. Nazir M, Shah FH. Studies on persian clover (Trifolium resupinatum). Plant Foods for Human Nutrition. 1985;1(37):3-8. doi: 10.1007/BF01092017.

6. Douglas SE. Chloroplast origins and evolution. Advances in Photosynthesis. 1994;91-118. doi: 10.1007/978-94-011-0227-8_5.

7. Daniell H, Lin C, Yu M, Chang W. Chloroplast genomes: diversity, evolution, and applications in genetic engineering. Genome Biology. 2016;17(1):134. doi: 10.1186/s13059-016-1004-2.

8. Palmer JD, Osorio B, Aldrich J, Thompson WF. Chloroplast DNA evolution among legumes: Loss of a large inverted repeat occurred prior to other sequence rearrangements. Current Genetics. 1987;11(4):275-286. doi: 10.1007/BF00355401.

9. Sveinsson S, Cronk Q. Evolutionary origin of highly repetitive plastid genomes within the clover genus (Trifolium). BMC Evolutionary Biology. 2014;14(1):228. doi: 10.1186/s12862-014-0228-6.

10. Barrett CF, Freudenstein JV, Li J, Mayfield-Jones DR, Perez L, Pires JC, Santos C. Investigating the path of plastid genome degradation in an early-transitional clade of heterotrophic Orchids, and implications for heterotrophic angiosperms. Molecular Biology \& Evolution. 2014;31(12):3095-112. doi: 10.1093/molbev/msu252.

11. Kearse M, Moir R, Wilson A, Stones-Havas S, Cheung M, Sturrock S, et al. Geneious Basic: An integrated and extendable desktop software platform for the organization and analysis of sequence data. Bioinformatics. 2012;28(12):1647-1649. doi: 10.1093/bioinformatics/bts199.

12. Kumar S, Nei M, Dudley J, Tamura K. MEGA: A biologist-centric software for evolutionary analysis of DNA and protein sequences. Briefings in Bioinformatics. 2008;9(4):299-306. doi:10.1093/bib/bbn017.

13. Cai Z, Guisinger M, Kim H, Ruck E, Blazier JC, Mcmurtry V, et al. Extensive reorganization of the plastid genome of Trifolium subterraneum (Fabaceae) is associated with numerous repeated sequences and novel DNA insertions. Journal of Molecular Evolution. 2008;67(6):696-704. doi: 10.1007/s00239-0089180-7.

14. Darling ACE, Mau B, Blattner FR, Perna ANT. Mauve: multiple alignment of conserved genomic sequence with rearrangements. Genome Research. 2004;14(7):1394-1403. doi:10.1101/gr.2289704.

15. Cheng H, Li J, Zhang H, Cai B, Mi L. The complete chloroplast genome sequence of strawberry (Fragaria $\times$ ananassa Duch.) and comparison with related species of Rosaceae. Peerj. 2017;5(10):e3919. doi:10.7717/peerj.3919.

16. Wong KS. KaKs_calculator: calculating Ka and Ks through model selection and model averaging. Genomics,Proteomics \& Bioinformatics. 2006;4:60-64. doi:CNKI:SUN:GPBI.0.2006-04-007

17. Kazutaka K, Standley DM. MAFFT multiple sequence alignment software version 7 : improvements in performance and usability. Molecular Biology \& Evolution. 2013;4(30):772-780. doi:

10.1093/molbev/mst010. 
18. Drummond AJ, Suchard MA, Xie D, Rambaut A. Bayesian phylogenetics with BEAUti and the BEAST 1.7. Molecular Biology \& Evolution. 2012; 29(8):1969-1973. doi:10.1093/molbev/mss075.

19. Raes J, Peer YVD. Functional divergence of proteins through frameshift mutations. Trends in Genetics Tig. 2005;21(8): 428-431. doi:10.1016/j.tig.2005.05.013.

20. Small RL, Cronn RC, Wendel JF. Use of nuclear genes for phylogeny reconstruction in plants. Australian Systematic Botany, 2004;17(2):145-170. doi:10.1071/sb03015.

21. Masood MS, Nishikawa T, Fukuoka S, Njenga PK, Tsudzuki T, Kadowaki K. The complete nucleotide sequence of wild rice (Oryza nivara) chloroplast genome: first genome wide comparative sequence analysis of wild and cultivated rice. Gene. 2004;340(1):0-139. doi:10.1016/j.gene.2004.06.008.

22. Su HJ, Hogenhout SA, Al-Sadi AM, Kuo CH. Complete chloroplast genome sequence of omani lime (Citrus aurantiifolia) and comparative analysis within the Rosids. Plos One. 2014;11(9):e113049. doi:10.1371/journal.pone.0113049.

23. Yu S, Wenpan D, Bing L, Chao X, Xin Y, Jie G, et al. Comparative analysis of complete chloroplast genome sequences of two tropical trees Machilus yunnanensis and Machilus balansae in the family Lauraceae. Frontiers in Plant Science. 2015;6:662-670. doi:10.3389/fpls.2015.00662.

24. Doorduin L, Gravendeel B, Lammers Y, Ariyurek Y, Chin-A-Woeng T, Vrieling K. The complete chloroplast genome of 17 individuals of pest species Jacobaea vulgaris: SNPs, microsatellites and barcoding markers for population and phylogenetic studies. DNA Research. 2011;18(2):93-105. doi:10.1093/dnares/dsr002.

25. Nei M, Kumar S. Molecular evolution and phylogenetics. Oxford University Press; 2000.

26. Yi L. Comparing and analyzing on models of calculation and statistical testing of nosynonymous substitution rate and synonymous substitution rate during gene evolution. Journal of Qujing Normal University. 2006;25(6):1-6.

27. Perry AS, Wolfe KH. Nucleotide substitution rates in legume chloroplast DNA depend on the presence of the inverted repeat. Journal of Molecular Evolution. 2002;55(5):501-508. doi:10.1007/PL00020998.

28. Bittner-Eddy PD, Crute IR, Holub EB, Beynon JL. RPP13 is a simple locus in Arabidopsis thaliana for alleles that specify downy mildew resistance to different avirulence determinants in Peronospora parasitica. Plant Journal for Cell \& Molecular Biology. 2010;21(2):177-188. doi:10.1046/j.1365313x.2000.00664.x.

29. Dong WL, Wang RN, Zhang NY, Fan WB, Fang MF, Li ZH. Molecular evolution of chloroplast genomes of Orchid species: insights into phylogenetic relationship and adaptive evolution. International Journal of Molecular Sciences. 2018;19(3):694-716. doi:10.3390/ijms19030716.

30. Zhang L. Collection and annotation of Suinong14 full-length transcripts and gene diversity analysis of Glyma13g21630. Chinese academy of agricultural sciences, 2011;37(10)®1724-1734. doi:10.3724/SP.J.1006.2011.01724.

31. Millen RS, Olmstead RG, Adams KL, Palmer JD, Lao NT, Heggie L, et al. Many parallel losses of infA from chloroplast DNA during angiosperm evolution with multiple independent transfers to the nucleus. The Plant Cell, 2001;13(3):645-658. doi:10.2307/3871412. 
32. Curci PL, De Paola D, Donatella D, Vendramin GG, Sonnante G. Complete chloroplast genome of the multifunctional crop globe artichoke and comparison with other Asteraceae. Plos One;10(3):e120589. doi:10.1371/journal.pone.0120589.

33. Xiao L. Intra-genomic polymorphism in the internal transcribed spacer (ITS) regions of Cycas revoluta: evidence of incomplete concerted evolution. 2009;17(5):476-481. doi:10.3724/SP.J.1003.2009.09100.

34. Flavell RB, Bennett MD, Smith JB, Smith DB. Genome size and the proportion of repeated nucleotide sequence DNA in plants. Biochemical genetics. 1974;12(4):257-269. doi:10.1007/BF00485947.

35. Haberle RC, Fourcade HM, Boore JL, Jansen RK. Extensive rearrangements in the chloroplast Genome of Trachelium caeruleum are associated with repeats and tRNA genes. Journal of Molecular Evolution. 2008;66(4):350-361. doi:10.1007/s00239-008-9086-4.

36. Wei YL, Wen ZF, Liu F, et al. Bioinformatics analysis of ycf1 gene in Corylus. Journal of Shanxi Agricultural Science. 2018;46(8):1244-1247. doi:10.3969/j.issn.1002-2481.2018.08.04.

37. Malaviya DR, Roy AK, Kaushal P, Kumar B, Tiwari A. Genetic similarity among Trifolium species based on isozyme banding pattern. Plant Systematics \& Evolution. 2008; 276(1-2):125-136. doi:10.1007/s00606-008-0070-7.

\section{Additional Files}

Additional file1: Table S1. Location and length of intron-containing genes in the chloroplast genomes of $T$. alexandrinum and T. resupinatum.

Additional file2: Table S2. The shared repeats of T. alexandrinum and T. resupinatum. * means the shared location for T. alexandrinum and T. resupinatum, res means locations particular for T. resupinatum, the numbers of "Number" mean number of repeats in T. alexandrinum and T. resupinatum, respectively.

Additional file3: Table S3. The relative synonymous codon usage (RSCU) analyzed using CodonW.

Additional file4: Table S4. Transversion (Tv) and transition ( $\mathrm{Tn}$ ) were detected between $T$. alexandrinum and T. resupinatum.

Additional file5: Table S5. The synonymous/synonymous substitution rates (Ka/Ks) calculated using 62 shared genes in T. alexandrinum and T. resupinatum.

Additional file6: Table S6. The nucleic acid polymorphism ( $\mathrm{Pi}$ ) computed using 88 common genes of $T$. alexandrinum and T. resupinatum.

\section{Figures}



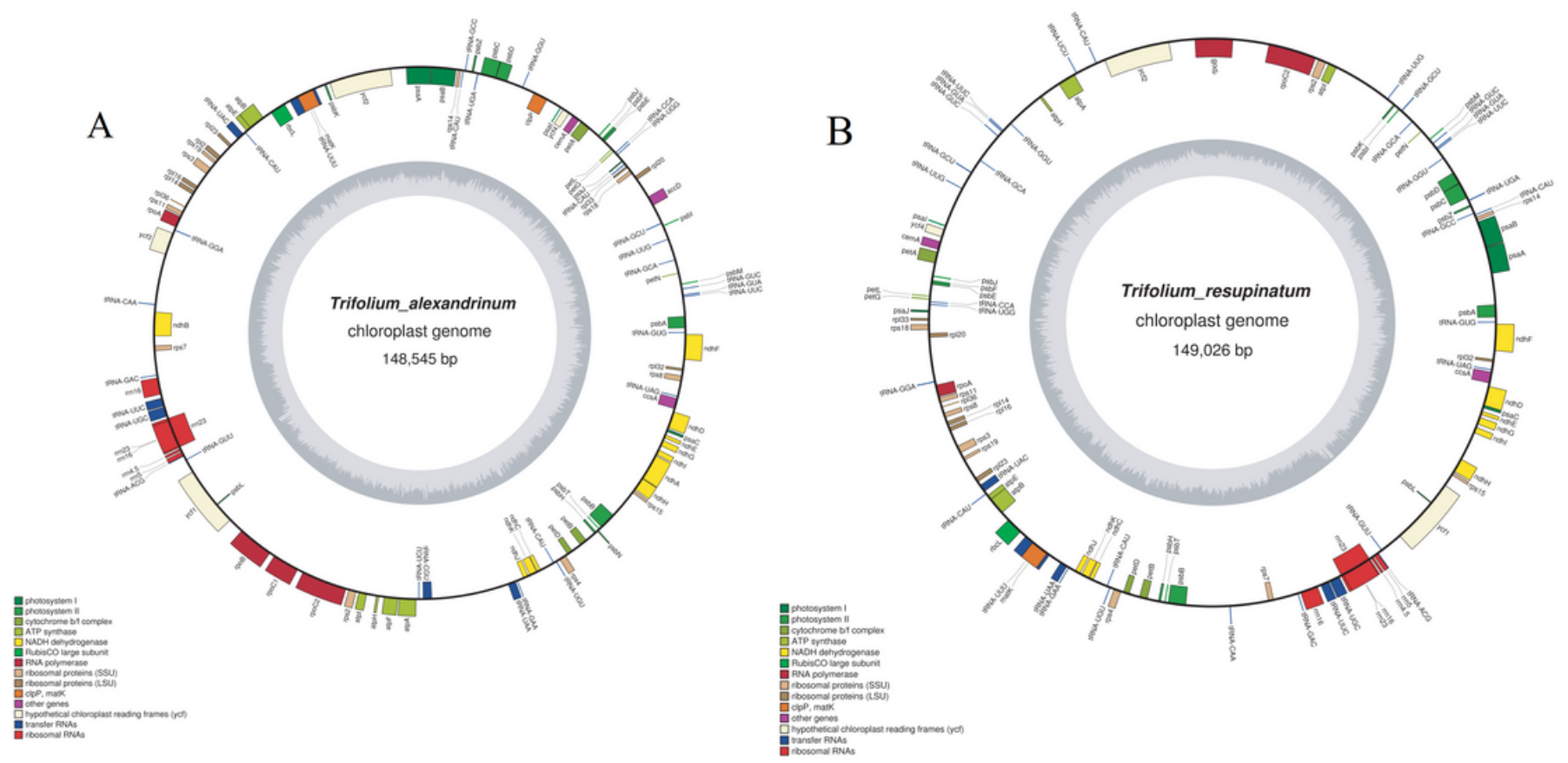

Figure 1

Gene maps of T. alexandrinum and T. resupinatum. Notes: Genes drawn inside and outside of the circle are transcribed clockwise and counterclockwise, respectively. Genes belonging to different functional groups are color coded. The darker gray color and lighter gray color in the inner circle corresponds to the GC content and the AT content, respectively. 

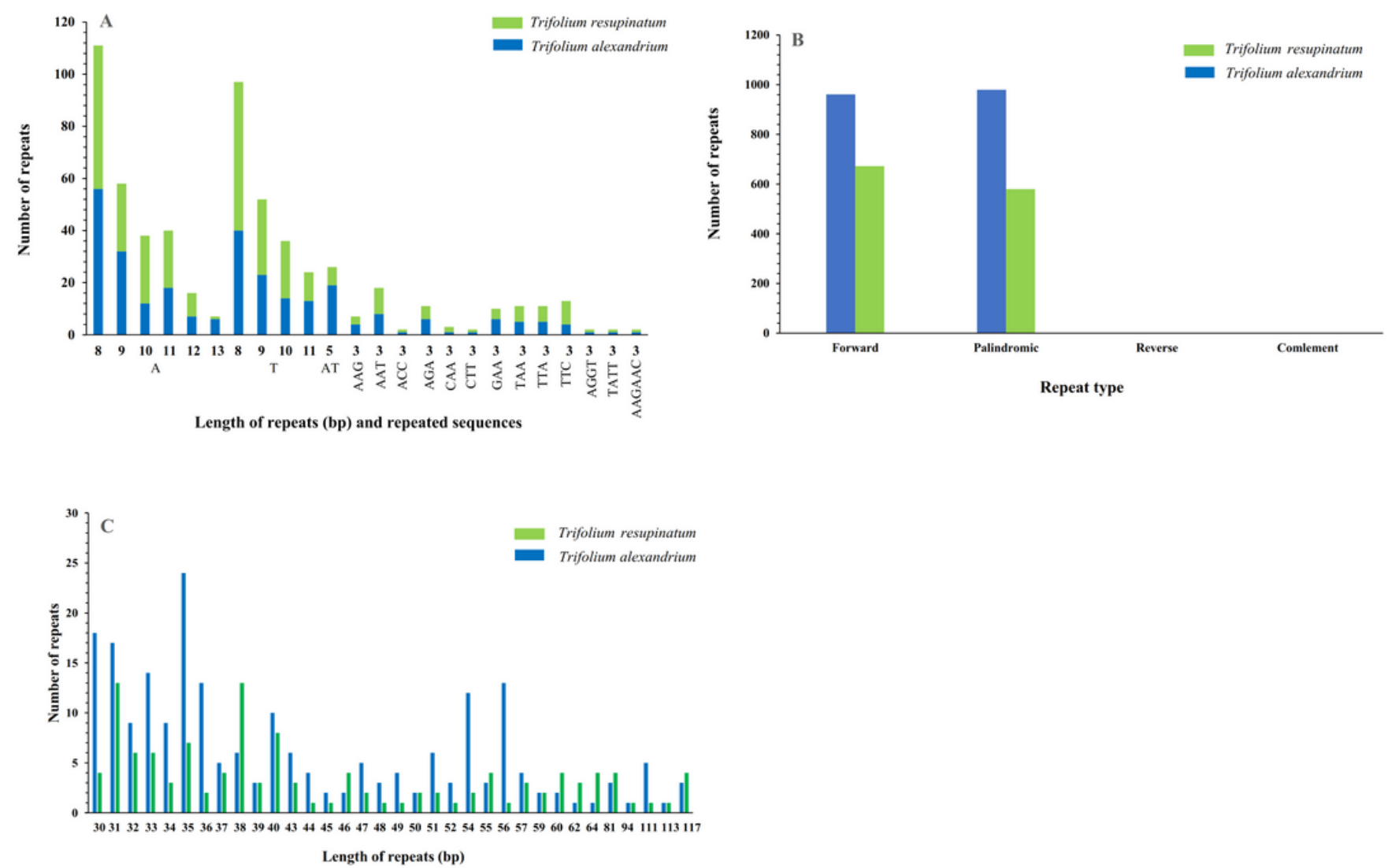

Figure 2

Repeating events of shared genes of T. alexandrinum and T. resupinatum. (A) Shared length of repeats and repeated sequences of T. alexandrinum and T. resupinatum; (B) Repeat type predicted in T. alexandrinum and T. resupinatum and (C) Listing of shared repetitive sequences with more than $30 \mathrm{bp}$. 


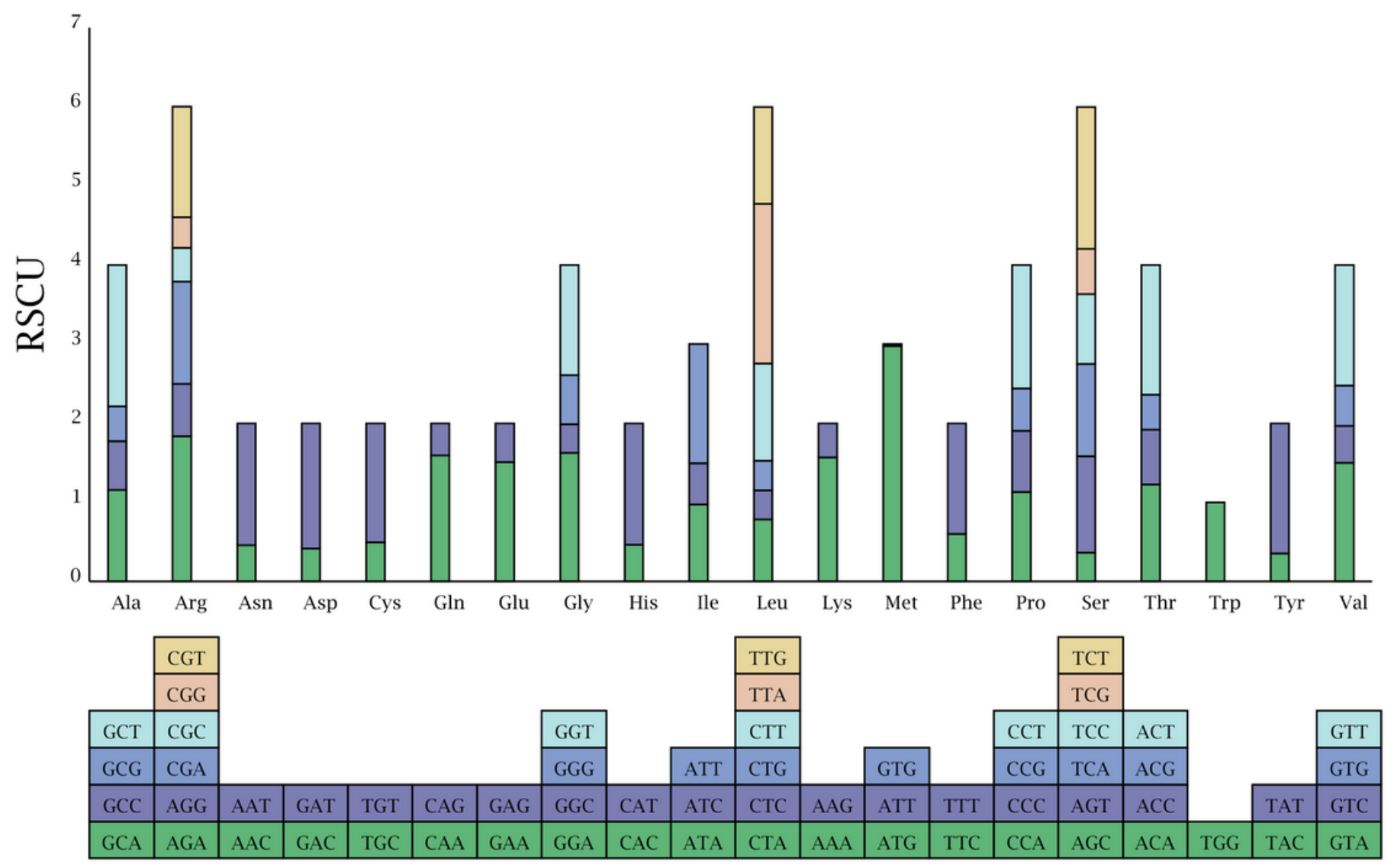

Figure 3

The relative synonymous codon usage (RSCU) for the T. alexandrinum and T. resupinatum. 


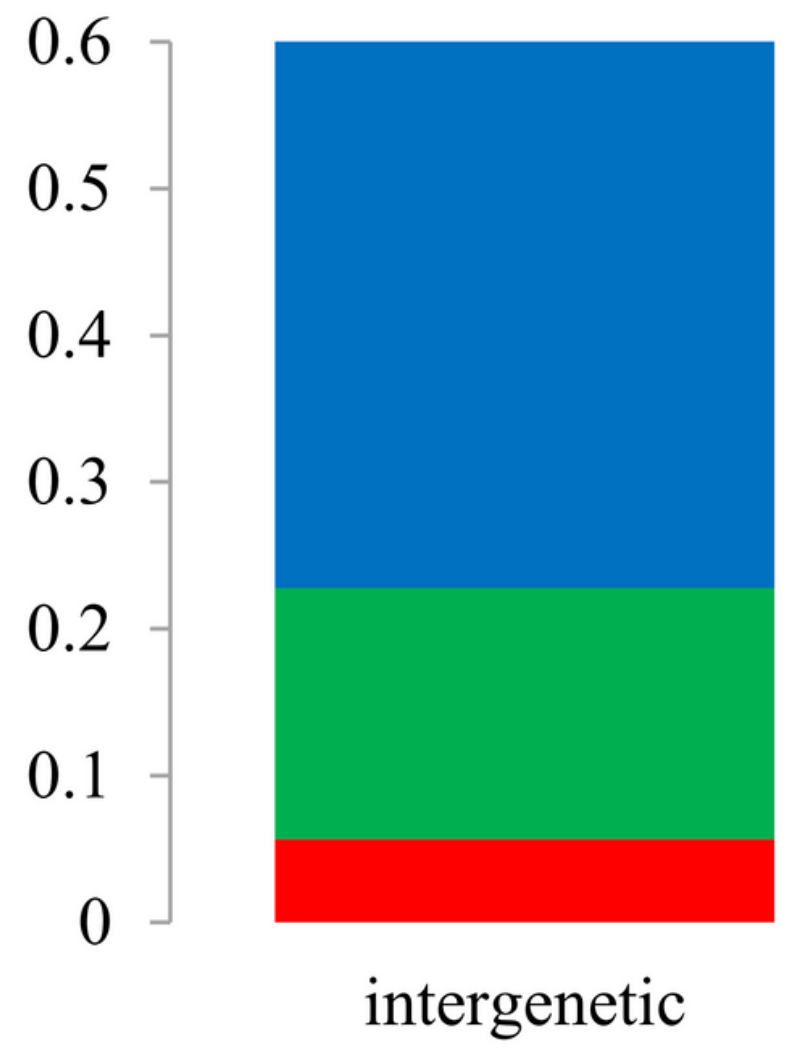

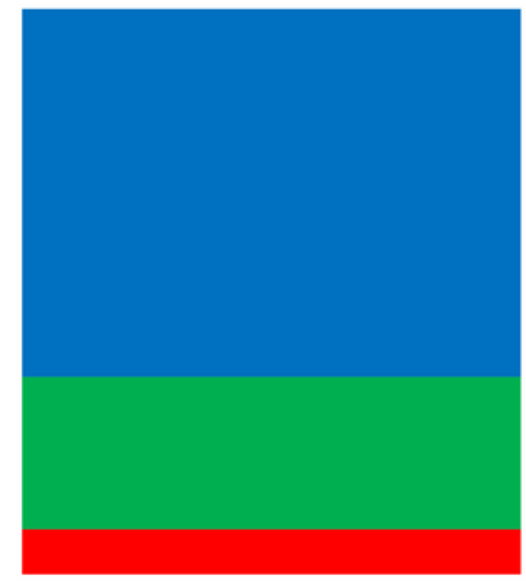

\section{genetic}

\section{Figure 4}

Transversion (Tv), transition (Tn) and Insert/Deletion (In/Del) were showed in intergenic and genic regions.

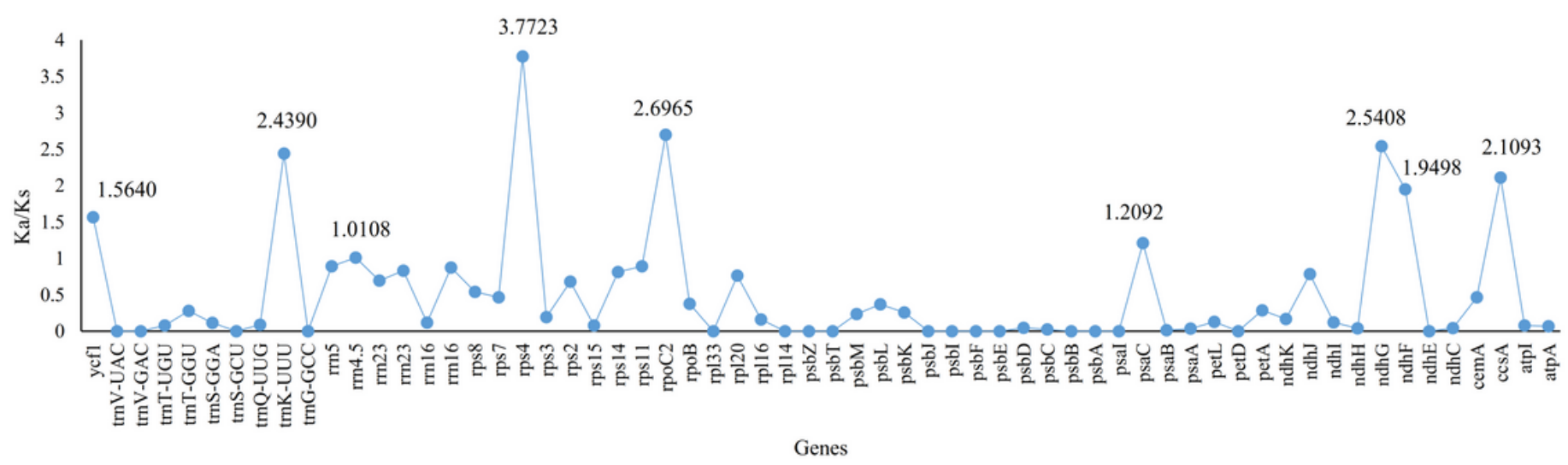

\section{Figure 5}

The synonymous/synonymous substitution rates $(\mathrm{Ka} / \mathrm{Ks})$ calculated using 62 shared genes in $\mathrm{T}$. alexandrinum and $\mathrm{T}$. resupinatum. 


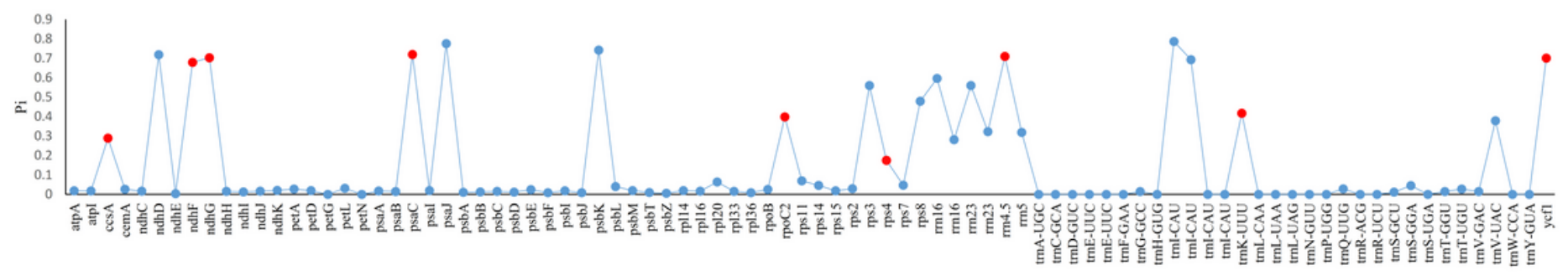

genes

\section{Figure 6}

The nucleic acid polymorphism (Pi) computed using 88 common genes of $\mathrm{T}$. alexandrinum and $\mathrm{T}$. resupinatum. Genes with more than one $\mathrm{Ka} / \mathrm{Ks}$ were red coded.

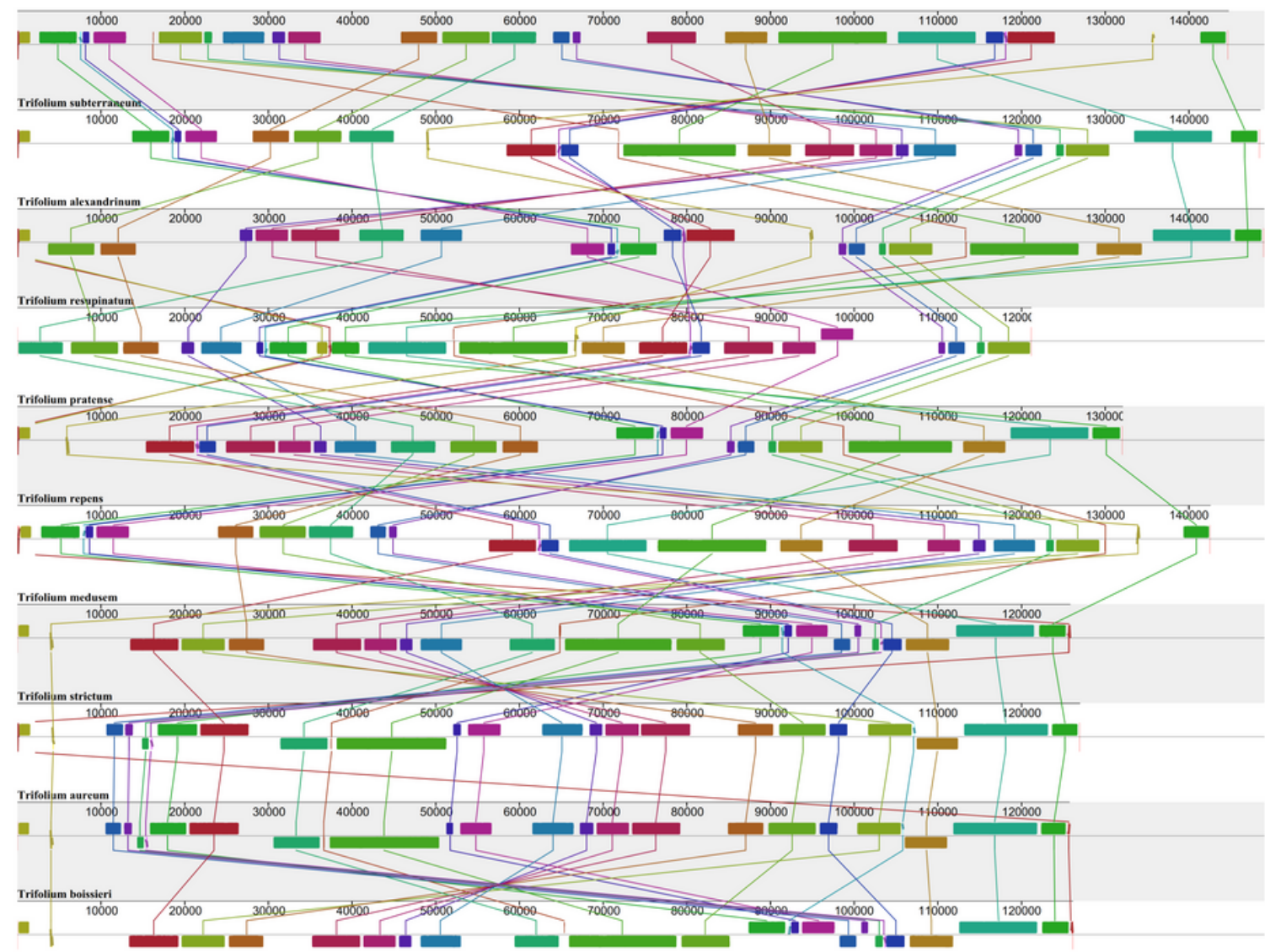

\section{Figure 7}

Synteny comparison of ten Trifolium chloroplast genomes with the reference of T. subterraneum using Mauve. Rectangular blocks with the same color indicate collinear regions. 


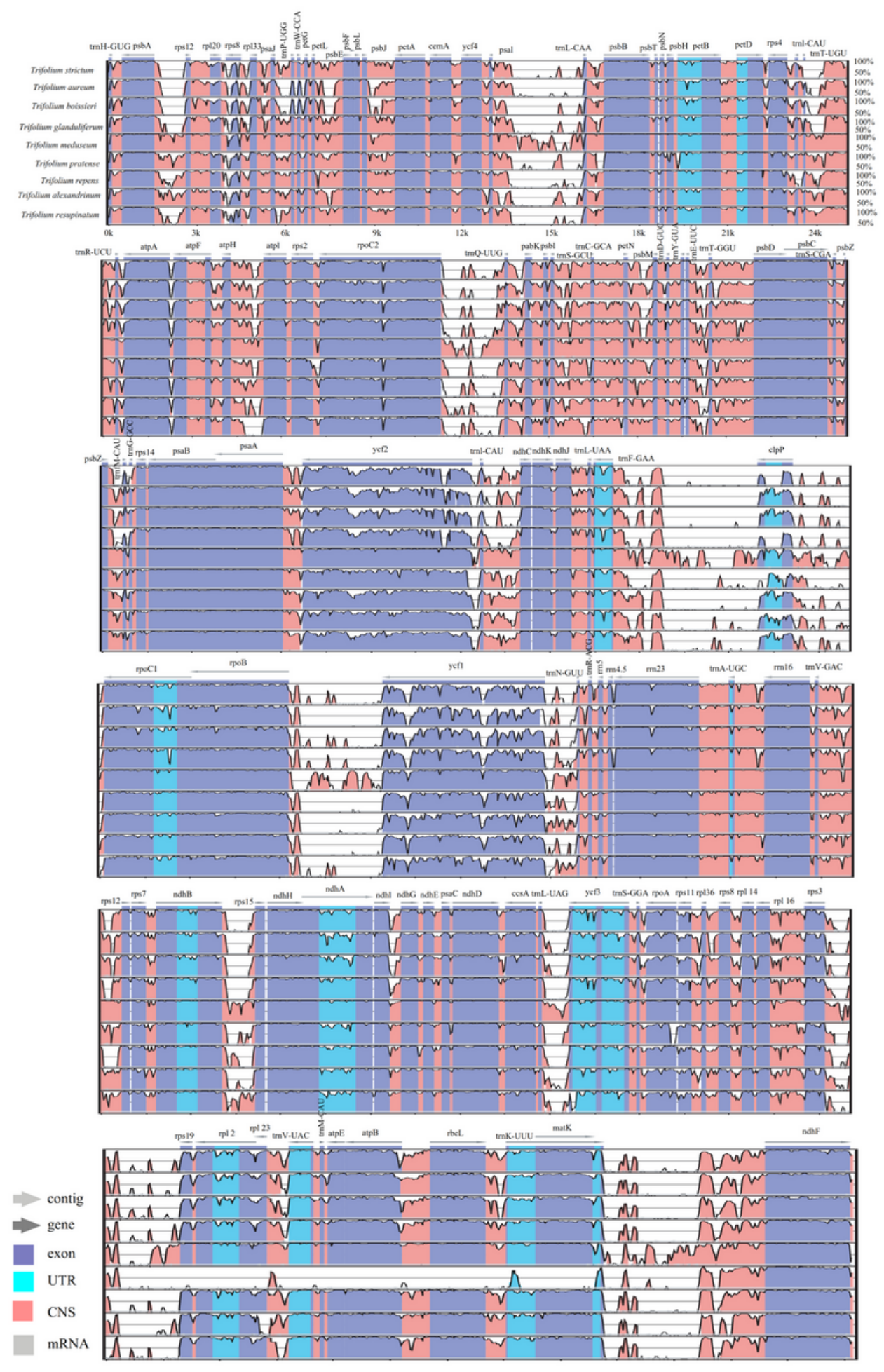

\section{Figure 8}

mVISTA alignment of the ten Trifolium cp genome sequences with $\mathrm{T}$. subterraneum as the reference. The horizontal axis indicated the coordinates within the $\mathrm{cp}$ genome. The vertical scale ranging from 50 to $100 \%$ indicated the percentage of identity. Genome regions are color coded as protein coding, exon, mRNA, untranslated regions (UTR) and conserved non-coding sequences (CNS). 


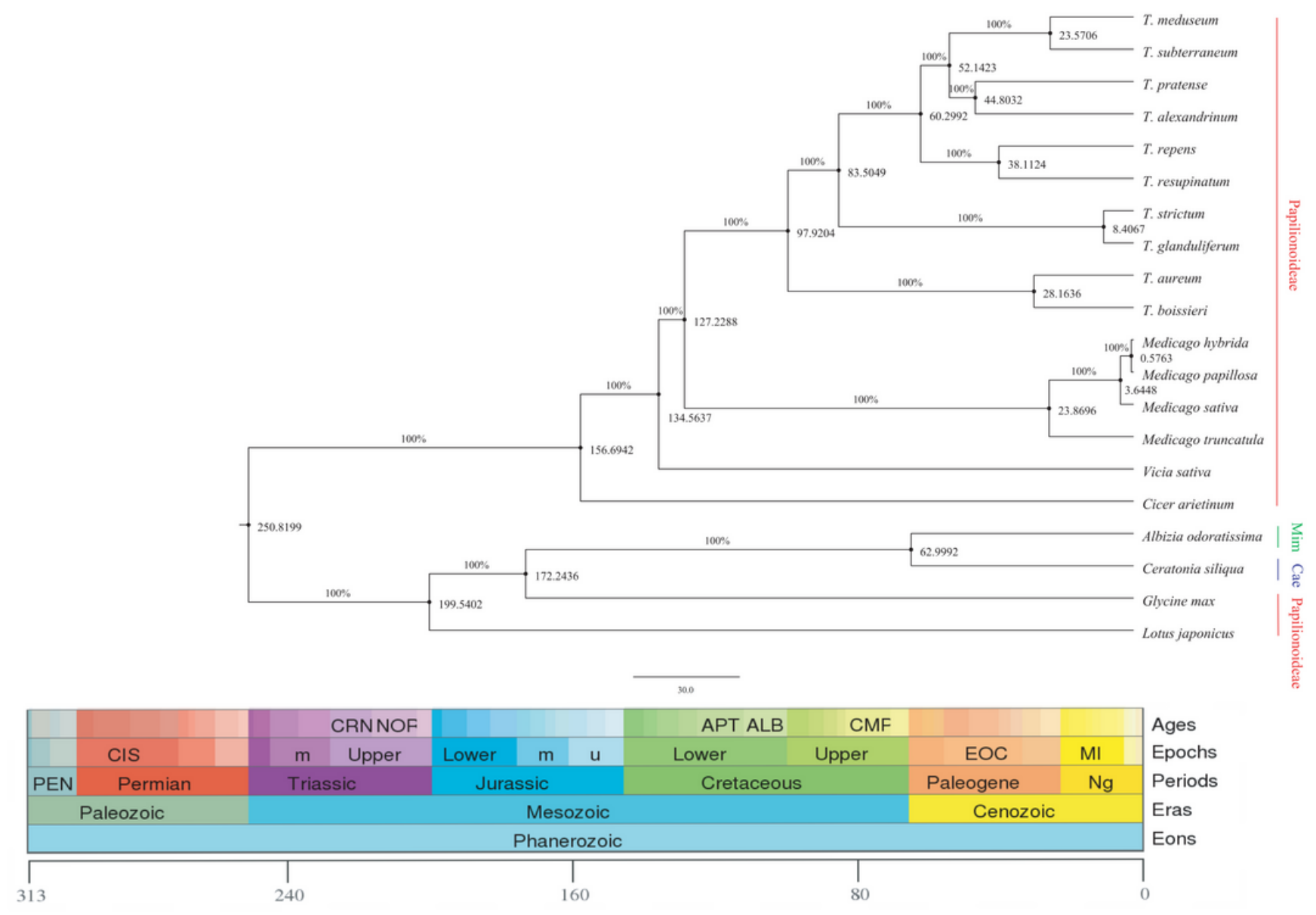

\section{Figure 9}

BEAST chronogram of the 20 Leguminosae species based on the common protein-coding genes. Geologic timescale was obtained from TIMETREE, time is shown in millions of years (MYA). Min, Mimosaceae; Cas, Caesalpinioideae.

\section{Supplementary Files}

This is a list of supplementary files associated with this preprint. Click to download.

- TableS4.xIsx

- Tables5.xlsx

- TableS1.docx

- TableS3.docx

- Tables2.docx

- Tables6.xIsx 